\title{
A Critical Evaluation of the Plenary Approaches to the Management of English Teaching of Large Classes
}

\author{
Xiao-Yi LIU \\ Foreign Language DepartmentJilin Business and Technology College Changchun, China \\ lihongbin1975@163.com
}

Keywords: evaluation; plenary approaches; large classes of English; teaching

\begin{abstract}
English Teaching of large classes is a common phenomenon throughout the world, especially in China. But there are also some problems along with it for the lack of communication and practice, even the poor management. This essay is presented to evaluate the plenary approaches in large classes by analyzing the roles the participants take in large classes, and by probing into the relationships between class size and the teachers' selection of approaches so that more appropriate approaches will be practiced in large classes.
\end{abstract}

\section{Introduction}

Large classes teaching is a common phenomenon throughout the world (Coleman; Project Report No.2 ). There is an increasing number of teachers becoming concerned about the influence of class size on language teaching and learning. According to Coleman's findings (Coleman; Project Report No.2), many teachers are worried about it and they argue that they can not practice communicative approach in their teaching, just because the class is too big. Meantime little theoretical attention has been given to the issue of language teaching and learning in large classes (ibid;). This essay is presented to evaluate the common approaches in large classes by analyzing the roles the participants take in large classes, and by probing into the relationships between class size and the teachers' selection of approaches. The critical evaluation of the approaches is carried out with reference to my personal teaching experience and the situation I am familiar with. It is not to speak against the plenary approaches or to force people to accept my ideas, but to investigate the relationship between class size and language teaching and learning, so that more appropriate approaches will be practiced in large classes.

\section{What to Evaluate}

Coleman and his group (Coleman: Project Report No. 11) have discovered that the common approaches practiced in large class teaching are that of plenary ones and that of interactive ones. A compromise approach that is a combination of the two is also practiced in large classes. In order to relate issues to the situation that I am familiar with and to be more practical, what I will discuss in this essay is not the interactive approaches or the compromise ones, but the plenary approaches which are still in practice (Coleman: Project Report No. 11).

\section{What the Teacher and the Students Might do in Large Classes}

Coleman and his group argue that there are two assumptions for the plenary approaches: a) there is no alternative, and b) let the people sing. They consider the first a lecture approach and the second a choral approach (ibid; ). If the assumptions are more or less universal, it then will be very easy to imagine what the teacher does and what the students do in large classes. So far as my experience is concerned, the practitioner in the first assumption is the complete controller of the class. It is his or her decision what to teach and how. In fact, the teacher seems to play a very important role in language teaching and learning process. Moreover, the role they play and the anticipatory nervousness large classes provide with them (Aronson: 1987, pp32) may lead to an effort-consuming 
preparation of their teaching in terms of the teaching content and teaching "method" and "techniques". They even have to prepare the very remarks they are going to say in class. Moreover they will probably have to prepare for every possible question that is likely to be raised in class. As for the second assumption, namely "let the people sing", the teacher takes a very similar role to that of the first, with the only difference being that the second gives a little freedom for the students to sing along with the teacher. Here it might be seen that the plenary teacher plays a role of an actor or an actress. In such classes, he or she tries to satisfy the students' demands by cramming their minds with their knowledge, and it might also be considered a disaster if the actor or actress retreats backwards off the cramming stage. A plenary approach class is actually a teacher-centered or teacher-controlled class (Coleman: Project Report No.11). The teacher does not encourage the students to ask questions even if they have some, because the teacher's instruction of "Any questions" (Frederick :1987 , pp45), either intentionally or not, does not seem to stimulate the students to ask questions. The students, like a recorder, have to do their best to memorize or note down the teacher's remarks or enjoy the performance of the teacher in the way they do in a theatre. In such a class, the teacher practices speaking English while students are compelled to listen to their teacher.

\section{Why Teachers and Students Take Their Different Roles in Class}

Coleman and his group (Project No.11) conclude that one of the reasons that teachers practice plenary approaches is that the teachers could see no alternatives. Another reason on which the plenary approaches are based is, as many teachers say, that they like lecturing. They have also found that in many cases class size is exploited as a convenient reason that they have to take the plenary approaches (Project No. 2 \&.11). According to their findings (Project No. 2), however, it is not always the case since the teachers do not seem to change the teaching methods with the change of the class size. If it is considered from the angle of methodology, it might be related to a) the concept of teaching, b) teachers' confidence, and c) innovation. One of the very differences between the traditional teaching approach and the communicative approach might be the work of the teacher-learner orientation or that of learner- learner orientation. People might have thought that teaching is a process of lecturing (Project No. 11), giving lessons or explanations to students on how to understand a text, a subject etc., which makes teaching totally isolated from students learning. Many teachers, especially old teachers, have long been used to the way they give lessons to their students. They might be hesitant about letting students teach them selves. Another factor might be that everyone does it in a similar way. Observation of others' teaching would make it possible for teachers to take it for granted that they teach in their own ways, especially when observation takes on an administrative form. There is another possibility that teachers do not know what and how other people are doing just because of lacking class observations. In such cases, It is only the teachers' thinking that plenary approaches are their only alternatives which are workable in large classes. In summary, whatever reasons, in many cases, as Allwright (Project Report No.12) says, teachers do not really have different behavior patterns either in small or large classes.

As to students, they have been used to the way they are taught. Few students would doubt the appropriateness of their teacher's teaching. Some do and they may carry on with their learning in a positive way. Allwright (Project Report No.12), by using examples from Safya Cherchalli (1988), states that some students consider lessons as unimportant events in their learning lives (ibid:), and that some students, instead of taking interest in what happens in class, seem to have their own ways to cope with their learning. However, the problem is, as was just said, that not all students are sensitive enough to realize that they could probably be given lessons in a more appropriate way. Probably it is not a bad thing. Otherwise they would doubt the value of attending the classes at school or university. The point I would like to achieve is that their age, their experience, and their levels of knowledge and their respect for their teachers-all these will not give students much room to doubt the way their teacher teaches them. Of course the teacher's good behavior to tell the students that they are good teachers even by cheating also plays a role in that part. A teacher from Malaysia, when asked what he would do if he does not know the answer to some questions raised in class, said he would ask the 
student to solve the problem himself instead of telling him that the teacher does not know the answer. It was based on the reason that honesty would make the students think the teacher s stupid. That is true for most of the primary and middle schoolteachers in China. One reason might be that the students expect too much from the teacher and the other reason is that teachers are taking the students' respect for the teachers too seriously. These two understandings interact with each other, leading to the wrong direction of academic acts.

To conclude, it is both the teacher and the students that contribute to the practice of the plenary approaches.

\section{Does Class Size Influence the Approaches the Teachers Take in Class}

It seems difficult to reach the same conclusion of how large a large class is. Different people have different concepts. As Coleman said (Project Report No. 4 pp35), class, size varies from country to country, and possibly also from one type of institution to another. They also argue that the opinion of the teacher is possibly what determines "small" or "large". In other words, the teacher's experience and his knowledge of other classes, the level of the schooling, the subject and the teacher's workload-all these may be among the factors which could influence the teacher's opinion of how large classes are. Coleman (Project Report No. 2) and his research group also conclude that the recruiting of new teachers for the purpose of reducing class size does not seem to be a proper solution to the management of large classes, and neither are bureaucratic actions likely to be. Actually as indicated in Part 4, whether teachers teach large classes or small classes, they do not actually change their teaching methods.

It is based on the selfishness of human nature that class size is used as a convenient excuse. In fact, it does not seem easy for a teacher to change his teaching pattern especially for those more experienced ones. A teacher who is good at using interactions in his ideal class size is not likely to replace the activities with a lecture if he is not supposed to. Similarly, a teacher who has been accustomed to using the plenary approaches in large classes will not necessarily be able to apply communicative approaches in his ideal class size.

So far it might be clear that there is no evidence that approaches alter with the change of class size. Class size is really not a problem, just a convenient excuse (Project Report No. 3). It might be the improper management of the teacher that affects the students' learning. If this is just the case, the matter will be simplified to the evaluation of the plenary approaches.

\section{Evaluation of the Plenary Approaches}

Although there are too many things to say about the plenary approaches, it is preferable to discuss them in terms of interaction, output, motivation, independence, teaching principle and meaningful learning.

\section{Interaction and Learning}

An outstanding feature of plenary approaches that might be drawn is that the" teacher only speaks to, not communicates with the student(s). There is also a lack of communication between the students themselves. It prevents students from using the rules they have just learnt more often as well as from having more speaking practice in the lesson. It actually takes away the possible learning practices in the classroom which Pride considers among the three variables for language acquisition - opportunity. It was found that students in most cases would like to talk to each other especially in the second half of the class if the teacher was not their class teacher or was not very strict. This might indicate that communication makes classes alive. Actually Coleman (1987: pl21-145) points out that each individual student and the teacher in large classes, as important classroom sources of data, bring to the classroom a certain amount of data for manipulation. He also discusses a list of interaction modes and tasks with the concluding remarks that the interrelated and interactive tasks can make students active and a lesson operate by itself. One of the important reasons might be that "the completion of a 
particular task is dependent on the satisfactory completion of all preceding tasks." (Coleman: 1987, ppl44)

In a word, as a Teton Lakota Indian (Frederick: 1987, pp45) said,

Tell me, and I'll listen.

Show me, and I'll understand.

Involve me, and I will learn.

\section{Input and Output}

An analysis of what teachers do and what students do in Part I will lead to the conclusion that one of the stages of learning takes up most of the class period or even the whole of the teaching activities. In other words, there is quite enough input, probably too much. The other stage - output or production is completely ignored. That is the more important of the two stages because the purpose of teaching is partly to help students use the language independently (Knapper: Large Classes and Learning pp6). Indeed it is output not input that defines the success of large class learning.

\section{Motivation and Demotivation}

As motivation is considered as one of three important variables for language acquisition (Rubin; 1979), how to motivate the students has become an important topic for social-psychologists, and linguists.

The plenary approaches are characterized by the lack of flexibility in the teaching process. Very often students are found either sleeping or talking in the latter part of the class. It is unfair to say they are not good students. Actually many students like large classes because they think they can make more friends there. The plenary approaches, not exploiting this advantage, may either take away the intrinsic motivation they had when starting to learn or cause difficulty in class control. The teacher may give fairly interesting examples to motivate his students, but it still remains at the level of enjoying the performance of the teacher the way they do in a theatre, if the student participation is not involved in the teaching and learning activities.

So tar as my experience is concerned, it is more communication than understanding that motivates the students. A variety of activities may make the class active and teaching easy for the teacher. In a word, it seems that plenary approaches are not a very successful means to motivate students.

\section{Teaching Principles and Meaningful Learning}

The plenary approaches really do not hold water if the 12 basic teaching principles (Brown: 1994) are taken into consideration. Meaningful learning (principle 2) says that too much use of explanation, examples and exercises designed to consolidate should be avoided. Indeed, language competence does not seem to be acquired with the students' good understanding of the teacher's explanation or with their repetition of what their teacher says. In a word, language acquisition seems to be accomplished by meaningful practice instead of by understanding only.

\section{Independence and Dependence}

In the plenary approaches, the explanation of the teacher becomes the target for the students to memorize. It might be very easy for them to become gradually dependent on the teacher's ideas not on the ideas of their own. Thus the value of the plenary approaches ought to be reconsidered since one of the teaching purposes is to help students to be "independent of solving problems" (Knapper:1987, pp6), using language and producing new language.

\section{Concluding Remarks on the Plenary Approaches}

As an approach, it might not be justified to jump to the conclusion that the plenary approaches are not as good as interactive or other approaches. Yet it seems to be evident that the approaches should be related to the course, the age of the learners, and the levels of the learners. 
In spite of that, interestingly, the plenary approaches have actually played a very important, if not very successful role in English teaching because they have got their own advantages;

a. Providing quite enough input.

b. Making learning receptive vocabulary effective because "learners remember best those items which have recurred many times." (Taylor: 1990, pp36)

c. Making the practitioner feel confident and comfortable.

As the centre of the class, the teacher has got quite an authority over the students as to making a decision of what to teach, how to teach etc. All these may give the teacher much confidence and even satisfaction in lecturing in large classes.

Presumably there are many other advantages with the plenary approaches. Yet the management of large classes has to be reconsidered if the teaching and learning goals are taken into consideration.

Now we might conclude the concluding remarks:

1) So far there is no evidence that the teacher applies some approach because of the class size, nor is there the evidence that the teacher changes his or her teaching pattern with the change of class size. The attitudes towards the class size seem to be more important than the reduction of class size.

2) Class size does not seem to be closely related to the results of students learning. Actually there are many advantages of large classes that could be exploited by large-class teachers.

3) The plenary approaches, with the evident advantages of providing quite enough input for the students, do have to be reconsidered because on one hand, they do not exploit the advantages of large classes, and on the other hand they do not meet the students' learning goals.

4) Definitely the plenary approaches still appeal to quite a number of teachers. Some of them may feel pleased and scholarly enough to lecture and tend to teach all his knowledge to the students. Some of them may feel guilty and unprofessional to think of letting the students teach each other and teach themselves, disclosing one reason why the approaches are still used in many parts of the world. Probably we still need lectures in large class teaching. Yet there is still one question for people to consider: how much lecturing do we need and to what degree can lecturing help students learn?

\section{Summary}

If you follow the "checklist" your paper will conform to the requirements of the publisher and facilitate a problem-free publication process.

\section{Acknowledgement}

This research was financially supported by the National Science Foundation.

\section{References}

[1] Allwright. D. Is Class Size A Problem? 1989.

[2] Allwright. D. How Important Are Lessons, Anyway Project Report No. 12.1989.

[3] Aronson J R. Six Keys to Effective Instructions in Large Classes. In Weimer. M G. Teaching Large Classes Well. Jossy-Bass Inc., Publishers, 1987. 31 37

[4] Brown H D. Teaching by Principles. Prentice Hall Regents, 1994.

[5] Coleman H. The Study of Large Classes. Project Report No. 2, 1989.

[6] Coleman H. Approaches of the Management of Large Classes, 1989.

[7] Coleman H. Little Tasks Make Large Classes Return. In Cross, D, Large Classes in Action; Prentice Hall International English.1995.121 145

[8] Coleman H. How Large Are Large Classes. Project Report No. 4 Project Report No.11, 1989.

[9] Frederick P J. Student Involvement: Active Learning in Large Classes.1987• 
[10]Weimer M G. Teaching Large Classes Well. Jossy-Bass Inc., Publishers, 1987. 45-47

[11]Knapper C. Large Classes and Learning. In Weimer, M G. Teaching Large Classes Well. Jossy -Bass Inc., Publishers, 1987.5 -15

[12] Rubm J. What a 'Good Language Learner' Can Teach Us. In Pride J B Sociolinguistic Aspects of Language Learning and Teaching. Oxford University Press, 1979.17 26

[13] Taylor L. Teaching and Learning Vocabulary. Prentice Hall, 1990. 